\title{
Evaluasi Kualitas Reviu Laporan Keuangan Kementerian: Studi pada Inspektorat Kementerian Pariwisata
}

\author{
Dewi Puspasari ${ }^{1}$, Arief Surya Irawan ${ }^{1}$ \\ 1) Fakultas Ekonomika dan Bisnis, Universitas Gadjah Mada
}

\begin{abstract}
The review of the financial statements carried out by the inspectorate has a major role in assisting the realization of a clean, transparent and accountable government, through the supervision of qualified state finances. This study aimed to evaluate the review quality of the ministry financial statements by the Inspectorate of the Ministry of Tourism and analyze the factors that become obstacles faced by the Inspectorate of the Ministry of Tourism in conducting the review of the financial statements. This study identified the review quality conducted by the parties involved in the review process of the ministry financial statements. The parties are the inspectorate as the reviewer and the work unit (satker) reviewed.
\end{abstract}

The results indicated that the review quality conducted by the Inspectorate of the Ministry of Tourism is included in the category of good review quality. The level of compliance showing the review quality from the inspectorate is $88,82 \%$ and from the satker is $85 \%$. Although the review of the Ministry of Tourism has a good quality, in 2012, however, it still got WDP opinion and disclaimer in the year 2013-2014. This is because the reviews and audits have different goals and procedures. The Inspectorate of the Ministry of Tourism does not review SPI so there is no SPI review value. Meanwhile BPK considered Ministry of Tourism SPI to determine audit procedures with the aim to provide opinion on the financial statements. During this period, the implementation of the review faced the obstacles of the delay in submitting financial statements, nomenclature changes, limited auditor numbers and competencies, limited time, and lack of budget support.

\begin{abstract}
Abstrak: Reviu atas laporan keuangan yang dilaksanakan oleh inspektorat memiliki peran yang besar dalam membantu mewujudkan pemerintahan yang bersih, transparan, dan akuntabel, dengan melalui pengawasan keuangan negara yang berkualitas. Riset ini bertujuan untuk mengevaluasi kualitas reviu atas laporan keuangan kementerian yang dilakukan oleh Inspektorat Kementerian Pariwisata dan menganalisis faktor yang menjadi kendala yang dihadapi oleh Inspektorat Kementerian Pariwisata dalam melaksanakan reviu atas laporan keuangan. Riset ini mengidentifikasi kualitas reviu yang dilakukan oleh pihak-pihak yang terlibat dalam proses reviu atas laporan keuangan kementerian. Pihak-pihak tersebut yaitu inspektorat sebagai pereviu dan satuan kerja (satker) yang direviu.

Hasil riset ini menunjukkan bahwa kualitas reviu yang dilakukan oleh Inspektorat Kementerian Pariwisata termasuk dalam kategori reviu yang berkualitas baik. Adapun tingkat kesesuaian yang menunjukkan kualitas reviu yaitu dari pihak inspektorat memperoleh $88,82 \%$ dan dari pihak satker memperoleh $85 \%$. Meskipun reviu Kementerian Pariwisata memiliki kualitas yang bagus namun pada tahun 2012 masih mendapat opini WDP dan disclaimer di tahun 2013-2014. Hal tersebut dikarenakan reviu dan audit memiliki tujuan dan prosedur yang berbeda. Inspektorat Kementerian Pariwisata tidak mereviu SPI sehingga tidak terdapat nilai reviu untuk SPI. Sedangkan BPK mempertimbangkan SPI Kementerian Pariwisata untuk menentukan prosedur pemeriksaan dengan tujuan untuk menyatakan pendapat atas laporan keuangan. Selama kurun waktu tersebut, pelaksanaan reviu menghadapi kendala keterlambatan satker dalam menyampaikan laporan keuangan, perubahan nomenklatur, keterbatasan jumlah dan kompetensi auditor, keterbatasan waktu, dan kurangnya dukungan anggaran.
\end{abstract}

Kata kunci: kualitas reviu, kendala reviu, peran APIP, Sistem Pengendalian Intern

\footnotetext{
${ }^{1}$ Corresponding author's email:mh_dewi@yahoo.co.id, arief.surya@ugm.ac.id
} 


\section{Pendahuluan}

Pemenuhan akuntabilitas dan transparansi pengelolaan keuangan negara terlaksana dengan penerbitan laporan keuangan kementerian/lembaga. Melalui Undang-Undang (UU) Nomor 1 Tahun 2004 dan Peraturan Pemerintah (PP) Nomor 8 Tahun 2006, setiap kementerian/lembaga Republik Indonesia diatur untuk menyelenggarakan akuntansi dan menyusun laporan keuangan. Penyelenggaraan dan penyusunannya harus mematuhi Standar Akuntansi Pemerintahan (Peraturan Pemerintah Nomor 71 Tahun 2010). Sistem Akuntansi Pemerintahan akan menghasilkan pelaporan keuangan, yang disampaikan tepat waktu dan direviu oleh Aparat Pengawasan Intern Pemerintah (APIP).

Pengelolaan laporan keuangan kementerian/lembaga memiliki sitem reviu. Laporan Keuangan Semesteran dan Tahunan disertakan dengan dokumen Pernyataan Tanggung Jawab (UU No.1/2004). Dalam dokumen semesteran dan tahunan, setiap kementerian/lembaga wajib memiliki pernyataan bahwa penyelenggaraan dan pengelolaan Anggaran Pendapatan dan Belanja Negara (APBN) telah mematuhi SAP. Dasar pembuatan Pernyataan Tanggung Jawab adalah reviu Inspektorat terhadap Laporan Keuangan dan Semesteran kementerian/lembaga. Hasil dari proses ini adalah Pernyataan Telah Direviu (PP No. 8/2006 pasal 33 ayat 3 dan PP No. 60/2008 pasal 57 ayat 1$)$.

Reviu merupakan salah satu upaya pemerintah melalui lembaga inspektorat dalam perwujudan pemerintahan yang bersih, transparan, dan akuntabel, melalui pengawasan keuangan negara yang berkualitas. Peraturan ini telah terlaksana sejak tahun 2010. Reviu bersifat sistem peringatan dini sebagai pencegah kekeliruan penyajian informasi keuangan. Melalui reviu, laporan keuangan diharapkan dapat terhindar dari masalah salah saji material.

Akan tetapi, sejumlah kementerian/ lembaga dicurigai belum mampu menjalankan pelaksanaan reviu secara optimal. Salah satu kementerian/lembaganya adalah Kementerian Pariwisata. Opini Badan Pemeriksa Keuangan (BPK) terhadap laporan keuangan Kementerian Pariwisata menguatkan kecurigaan. Kementerian Pariwisata memperoleh opini Wajar Dengan Pengecualian (WDP) pada tahun 2012, lalu menurun menjadi opini disclaimer pada tahun 2013-2014. Meskipun mereka memperoleh opini Wajar Tanpa Pengecualian (WTP), evaluasi pelaksanaan reviu tersebut perlu dilaksanakan, dengan tujuan pelaksanaan reviu tidak hanya unuk mempertahankan opini, namun juga dapat lebih dioptimalkan. Selain itu, literatur sebelumnya terbatas pada identifikasi kualitas reviu dari pihak pereviu, sedangkan riset ini bertujuan mengidentifikasi kualitas reviu dari sisi pihak-pihak yang terlibat dalam proses reviu atas laporan keuangan kementerian. Riset ini memiliki dua pertanyaan penelitian besar sebagai berikut.

1. Bagaimana kualitas reviu atas laporan keuangan kementerian yang dilakukan oleh Inspektorat Kementerian Pariwisata?

2. Mengapa terjadi ketidakoptimalan reviu atas laporan keuangan Kementerian Pariwisata?

\section{Kajian Literatur}

Dalam konteks Indonesia, ruang lingkup reviu atas Laporan Keuangan Kementerian/ Lembaga adalah penelaahan atas penyelenggaraan akuntansi dan penyajian laporan keuangan kementerian. Reviu tidak menyerupai audit, maka reviu tidak melaksanakan pengujian sistem pengendalian intern, catatan akuntansi, dan dokumen sumber, serta pengujian atas respon permintaan keterangan. 
Pendefinisian reviu sendiri memiliki banyak opini sebagai berikut.

a. Pertama, Standar Profesional Akuntan Publik menyebutkan bahwa reviu atas laporan keuangan adalah pelaksanaan prosedur permintaan keterangan dan analisis memadai untuk memberikan keyakinan terbatas bahwa tidak ada modifikasi material atas laporan keuangan sehingga prinsip berlaku umum diterapkan dalam penyusunan laporan keuangan.

b. Kedua, Peraturan Menteri Keuangan No. 41/PMK.09/2010 mengartikan reviu sebagai penelaahan penyelenggaraan akuntansi dan penyajian laporan keuangan oleh auditor APIP yang kompeten untuk memberikan keyakinan terbatas bahwa penyelenggaraan akuntansi telah mematuhi Sistem Akuntansi Instansi dan disajikan sesuai SAP.

c. Ketiga, Peraturan Menteri Pendayagunaan Aparatur Negara

No.

PER/05/M.PAN/03/ 2008 menyebutkan reviu sebagai proses penelaahan ulang buktibukti suatu kegiatan untuk memastikan bahwa pelaksanaannya telah sesuai dengan keberlakuan suatu ketentuan, standar, rencana, maupun norma.

d. Keempat, Peraturan Direktur Jenderal Perbendaharaan Nomor PER-44/PB/2006 mendefinisikan reviu sebagai prosedur penelusuran angka dalam laporan keuangan, permintaan keterangan, dan analitik sebagai dasar memadai bagi APIP untuk memberi- kan keyakinan terbatas bahwa tidak ada modifikasi material atas penyusunan laporan keuangan.

Guna membedakan pemahaman antara reviu dan audit, Tabel 1 merangkum perbedaan pengertian reviu dan audit dari sisi keyakinan, sistem pengendalian internal (SPI), output, dan pengguna.

Sementara itu, tahapan reviu dapat dilihat pada Bagan 1 berikut. PMK No. 41 Tahun 2010 membagi tahapan reviu menjadi 3 tahapan besar, yakni perencanaan, pelaksanaan, dan pelaporan. Pertama, tahap perencanaan, pereviu menyeleksi dan menentukan objek reviu berupa proses penyelenggaraan akuntansi dan rekening akun penting. Kedua, tahap pelaksanaan, pereviu berfokus pada penyusunan Kertas Kerja Reviu (KKR). Ketiga, tahap pelaporan, pereviu mengungkapkan tujuan dan alasan pelaksanaan, prosedur riil, temuan/ kesalahan, langkah perbaikan.

Seorang pereviu diharapkan memiliki sejumlah kompetensi. Melalui Peraturan Menteri Keuangan Nomor 41/PMK.09.2010, kompetensi kolektifnya adalah penguasaan Standar Akuntansi Pemerintahan dan Sistem Akuntansi Instansi, pemahaman proses bisnis unit akuntansi, penguasaan dasar-dasar audit, teknik komunikasi, dan analisis basis data. Sementara itu, secara umum, kompetensi pereviu adalah kemampuan memahami akuntansi pemerintahan dan lima komponen dari sistem pengendalian internal.

Tabel 1

Perbedaan Audit dan Reviu

\begin{tabular}{clll}
\hline No. & \multicolumn{1}{c}{ Aspek } & \multicolumn{1}{c}{ Audit } & \multicolumn{1}{c}{ Reviu } \\
\hline 1. & Keyakinan & Memadai & Terbatas \\
2. & SPI & Dasar menilai risiko audit & Telaah + rekomendasi \\
3. & Output & Opini & Rekomendasi + Dasar Pernyataan Manajemen \\
4. & Pengguna & Pemangku Kepentingan & Internal Manajemen \\
\hline
\end{tabular}


Sumber: (Ritonga, 2010)

Perencanaan
$\begin{gathered}\text { Seleksi dan pemilihan objek reviu, proses } \\ \text { akuntansi, dan akun laporan keuangan }\end{gathered}$
Pelaksanaan
Penelaahan peny elenggaraan akuntasi;
Kertas Kerja Reviu (KKR) berisi identitas
penyusun, unit reviu, lingkup reviu,
langkah-langkah reviu, dan kesimpulan
pelaksanaan reviu
Pelaporan
Mengungkap tujuan dan alasan pelaksanaan,
prosedur reviu temuan kesalahan,
langkah perbaikan terlaksana, dan saran
perbaikannya.
Terwujud dalam Laporan Hasil Reviu (LHR)

Bagan 1. Tahapan Reviu

Melaksanakan kegiatan reviu berarti menelusuri sistem pengendalian intern (SPI). SPI pemerintahan Indonesia mengadopsi pengertian pengendalian intern dari COSO (Committee of Sponsoring Organization). COSO mendefinisikan pengendalian intern sebagai penjaminan mutu dan tujuan organisasi atau entitas oleh dewan komisaris, manajemen, dan karyawannya. Sementara itu, Peraturan Pemerintah Nomor 60 Tahun 2009 tentang Sistem Pengendalian Intern Pemerintah (SPIP) mendefinisikan SPI sebagai proses integrasi pada tindakan dan kegiatan berkelanjutan oleh pimpinan dan seluruh pegawai dalam memberikan keyakinan memadai bahwa ketercapaian tujuan dicapai melalui keefektifan dan efisiensi kegiatan, keandalan laporan keuangan, pengamanan aset negara, dan kepatuhan terhadap perundangundangan. Tata kelola SPI dalam lingkungan kementerian/lembaga dapat dilihat pada Bagan 2 berikut.

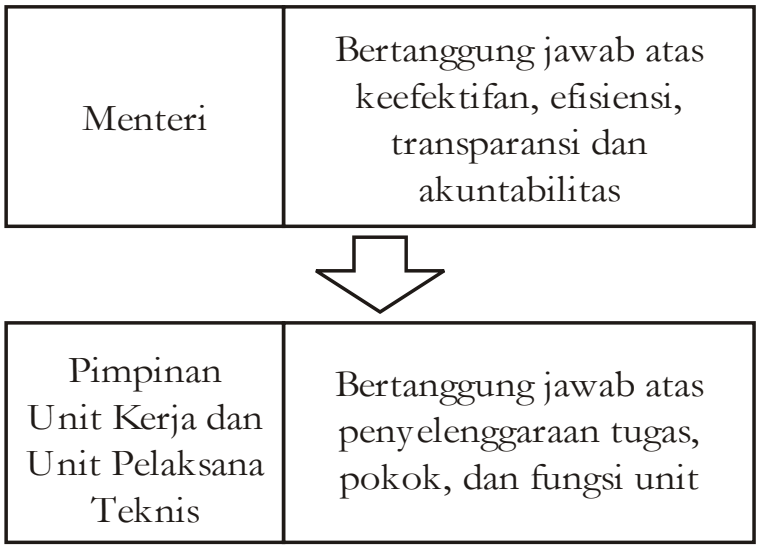

Bagan 2. Pertanggungjawaban SPIP

SPIP mengadopsi 5 komponen pengendalian intern $\mathrm{COSO}$, dengan penyesuaian sesuai lingkungan kerja pemerintah. Berikut adalah 5 komponen pengendalian intern SPIP dengan pelaksananya adalah pimpinan unit kerja atau uni

a. Lingkungan Pengendalian, bertujuan menciptakan perilaku positif dan kondusif melalui sejumlah aktivitas, yakni penegakan integritas dan nilai etika, penyesuaian kompetensi dengan tugas dan fungsi, kondusifnya kepemimpinan, struktur organisasi sesuai dengan kebutuhan, ketepatan dalam pendelegasian wewenang dan tanggung jawab, sehatnya penyusunan dan penerapan kebijakan, keefektifan peran aparat pengawasan intern pemerintah, dan terjalinnya hubungan baik dengan instansi pemerintah terkait.

b. Penilaian Risiko, memuat 2 hal penting, yakni penetapan tujuan intstansi secara spesifik, terukut, dapat tercapai, realistis, dan terikat waktu, lalu, tujuan kegiatan relevan dengan tujuan dan rencana strategis unit, harmonisasi antar unit (saling melengkapi, menghindari konflik, dan dukungan sumber daya unit lain), dan adanya kriteria pengukuran.

c. Kegiatan Pengendalian, adanya kesesuaian dengan ukuran, kompleksitas, dan sifat dari 
tugas dan fungsi unit kerja. Kegiatan ini dikaitkan dengan proses penilaian risiko dan disesuaikan dengan sifat khusus unit. Selain itu, evaluasi dilakukan terhadap prosedur tertulis, sehingga dapat menggali potensi kegagalan kegiatan pengendalian.

d. Informasi dan Komunikasi, pembentukan informasi melalui proses identifikasi, pencatatan, dan penyampaian informasi. Keefekfian komunikasi tercapai melalui implementasi dan pembaharuan sarana dan bentuk komunikasi terkini.

e. Pemantauan Pengendalian Intern, proses dipantau dan dievaluasi secara berkelanjutan. Pimpinan menindaklanjuti rekemondasi hasil audit dan reviu.

Berbicara mengenai kualitas, maka harus dapat memahami definisinya secara umum maupun spesifik. Secara umum, kualitas adalah tingkatan baik atau buruk, sedangkan secara spesifik, kualitas berarti kondisi dinamis dan pengaruh terhadap produk, jasa, manusia, proses, dan lingkungan terhadap ekspektasi dan harapan (Tjiptono, 2007). Dalam konteks pelayanan, kualitas pelayanan berarti upaya pemenuhan kebutuhan konsumen dan ketepatan penyampaiannya. Dari proses reviu Laporan Keuangan Kementerian/Lembaga, pemberi layanan adalah inspektorat, sedangkan satuan kerja adalah konsumen.

Karakteristik reviu hampir menyerupai karakteristik audit, sehingga peninjauan literatur mengenai kualitas audit perlu dilakukan untuk menganalisis kualitas reviu. Riset ini menggunakan kriteria kualitas reviu dari artikel Windarsih (2015), yang dimodifikasi dari artikel Behn, Carcello, Hermanson, dan Hermanson (1997). Riset tersebut bertujuan menguji empiris tentang faktor-faktor kualitas audit dan hubungannya dengan kepuasan klien. Hasil penelitian Windarsih (2015) menunjukkan bahwa tingkat kualitas reviu Inspektorat Kabupaten Klaten cukup tinggi. Kemudian, Dona (2013) mengevaluasi reviu Inspektorat Kota Payalumbuh terhadap Laporan Keuangan Pemerintah Daerah (LKPD). Berlandaskan pada kriteria Permendagri Nomor 4 Tahun 2008, hasil risetnya menunjukkan bahwa Inspektorat Kota Payakumbuh belum sepenuhnya melaksanakan reviu sesuai dengan permendagri tersebut. Catatan dari Dona (2013) adalah keterbatasan sumber daya manusia, minimnya kesempatan dan pelaksanaan pelatihan, dan tekanan waktu.

\section{Metoda}

Riset ini bertujuan untuk memperoleh informasi mengenai kualitas reviu Laporan Keuangan dan menganalisis hambatan di lingkungan Kementerian Pariwisata. Maka, riset ini menerapkan pendekatan kualitatif deskriptif dengan studi kasus. Jenis data adalah data primer dan sekunder. Data primer diperoleh melalui wawancara dan diskusi grup, dengan subjeknya adalah tim reviu laporan keuangan kementerian/lembaga pada tahun 2012 hingga 2014 dan satuan kerja tereviu. Sementara itu, peneliti memperoleh data sekunder melalui arsip dan dokumen permasalahan, seperti surat tugas reviu, program kerja reviu, laporan hasil reviu, laporan hasil audit BPK (Badan Pemeriksa Keuangan), dan datadata tentang tugas dan fungsi dan inspektorat. Peneliti menerapkan dua teknik pengumpulan data, yakni riset lapangan dan riset kepustakaan.

Pertama, riset lapangan dilaksanakan untuk menggali data dan informasi secara langsung di Inspektorat Kementerian Pariwisata. Ada 3 metoda riset lapangan pada riset ini.

a. Dokumentasi. Melalui penelaahan data dan informasi dari objek riset. 
b. Wawancara. Peneliti mewawancarai sejumlah pihak terkait yang bertugas melakukan reviu. Peneliti menetapkan 9 informan wawancara, yakni 4 auditor dan 5 dari satuan kerja. Kelima satuan kerja adalah Deputi Bidang Pengembangan Destinasi dan Industri Pariwisata, Deputi Bidang Pengembangan Pemasaran Pariwisata Mancanegara, Deputi Bidang Pengembangan Pemasaran Pariwisata Nusantara, dan Deputi Bidang Pengembangan Kelembagaan Kepariwisataan sebagai penyusun laporan keuangan pada tingkat UAPPA-E1, dan Biro Perencanaan dan Keuangan pada Sekretariat Kementerian Pariwisata sebagai penyusun laporan keuangan pada tingkat UAPA.

Sesi wawancara mendalam mengandung 8 pertanyaan inti sebagai berikut.

1. Apakah reviu penting dalam mewujudkan pengelolaan keuangan yang baik dan bagaimana peran Inspektorat mewujudkan transparansi dan akuntabilitas dalam penyelenggaraan pemerintah melalui reviu $\mathrm{LK} \mathrm{K} / \mathrm{L}$ ?

2. Bagaimana keterlibatan inspektur dalam pelaksanaan reviu LK K/L?

3. Apa usaha yang dilakukan untuk meningkatkan kualitas reviu LK K/L?

4. Apakah dilakukan pemahaman entitas sebelum pelaksanaan reviu?

5. Apakah ketua tim menyusun PKR sebelum melaksanakan reviu LK K/L?

6. Apakah para auditor memahami SAP, Peraturan Menteri Keuangan Nomor 41/PMK.09/2010, dan SPIP?

7. Bagaimana perwujudan sikap skeptis dalam melaksanakan reviu LK K/L?

8. Bagaimana sikap tim reviu jika mempunyai gangguan independensi?

c. Diskusi grup. Peneliti melaksanakan diskusi interaktif dengan 6-8 partisipan, dipimpin moderator terlatih, dan berfokus pada sejumlah isu secara spesifik (Hennink, Hutter, \& Bailey, 2011). Sebelum diskusi grup dimulai, moderator membuka sesi pengantar sebagai perkenalan dan penyampaian maksud riset. Kemudian, proses diskusi grup dimulai dengan sesi pertanyaan pembuka dan pertanyaan pengantar yang diisi dengan pertanyaan singkat, faktual dan mengundang kontribusi partisipan. Pertanyaan bersifat umum. Suasana diskusi kondusif untuk berdiskusi, karena sesama anggota diskusi telah memulai interaksi. Moderator memasuki pertanyaan transisi yang berisikan pertanyaan tentang lingkungan Kementerian Pariwisata. Anggota diskusi menceritakan pengalaman dan tantangan Kementerian Pariwisata dalam pengelolaan dan penyelenggaraan laporan keuangannya. Bahasan diskusi mulai spesifik karena bahasan kualitas reviu mulai dipaparkan oleh partisipan. Moderator memimpin sesi diskusi dan tanya-jawab tentang kegiatan reviu Inspektorat Kementerian Pariwisata. Setelah diskusi grup mampu mencapai simpulan dan membentuk pemikiran ideal, moderator menutup diskusi grup dengan memberikan konfirmasi ringkasan hasil diskusi dan memaparkan bahasan isu.

Partisipan diskusi grup adalah Auditor Madya, Auditor Muda, Auditor Pertama, Kepala Subbagian Akuntansi I pada Biro Perencanaan dan Keuangan, Kepala Subbagian Akuntansi II pada Biro Perencanaan dan Keuangan, Operator Sistem Akuntansi Instansi (SAI) pada Biro Perencanaan dan Keuangan Sekretariat, dan Operator Sistem Manajemen dan Akuntansi Barang Milik Negara (SIMAK BMN) pada Biro Umum Sekretariat.

Kedua, peneliti melaksanakan riset kepustakaan, yakni mengumpulkan sejumlah 
berkas dan dokumen hasil pelaksanaan reviu Inspektorat Kementerian Pariwisata. Berkas dan dokumen tersebut adalah (1) Surat Tugas Reviu, (2) Program Kerja Reviu, (3) Kertas Kerja Reviu, (4) Laporan Hasil Reviu, (5) Laporan Hasil Audit BPK, dan (6) Laporan Keuangan Kementerian, serta dokumen terkait lainnya.

Setelah melaksanakan wawancara dan diskusi grup, peneliti melakukan tiga tahapan analisis data kualitatif (Miles \& Huberman, 1984). Pertama, peneliti mereduksi data dengan cara memilah hal-hal pokok dan berfokus pada hal penting agar memperoleh tema dan pola dari bahasan. Informan wawancara berpotensi memaparkan hal-hal di luar maksud riset, sehingga reduksi data dapat membantu analisis data lebih spesifik. Kedua, peneliti menyajikan data berupa kode dan tema ke dalam sebuah tabel. Kesamaan karakteristik pada suatu tema diberi kode sama. Pemberian nama kategori didasarkan kriteria peneliti pada faktor penentu kualitas reviu (Windarsih, 2015). Ketiga, penarikan kesimpulan dapat dilakukan apabila dokumen terkait telah terkumpul secara andal dan valid.

Pendekatan studi kasus dalam analisis kualitatig dapat melalui penelurusan kesesuaian antara praktik dan fakta lapangan dengan kriteria atau standar kualitas reviu. Peneliti menerapkan 3 langkah prosedur evaluasi sebagai berikut.

a. Menggunakan kriteria dan indikator dari riset (Windarsih, 2015)

b. Menghitung dan membandingkan tingkat kesesuaian dengan kriteria

c. Menyimpulkan tingkat kesesuaian sebagai indikasi tingkat kualitas reviu

Indikator penilaian dapat dirumuskan dengan sebuah formula. Teknik perhitungan menerapkan ukuran persentasi dari perolehan nilai sebagai berikut.

$$
\mathrm{x}=\frac{\text { Total nilai yang diperoleh }}{\text { Total indikator }} \times 100 \%
$$

Keterangan: $\mathrm{x}=$ tingkat kesesuaian pelaksanaan reviu atas laporan keuangan kementerian

Kategori persentase: 90-100\%: sangat baik, 70-89: baik, 50-69\%: cukup baik, 0-49\%: kurang baik

Keabsahan perolehan data dan informasi dari proses wawancara dan diskusi grup harus diuji. Untuk mengatasi keraguan akan keabsahannya, peneliti menerapkan teknik triangulasi. Secara konsep, teknik triangulasi adalah pengujian kredibilitas melalui pemeriksaan perolehan data pada beberapa sumber. Peneliti membandingkan keadaan dan perspektif seseorang dengan berbagai pendapat dan pandangan dari auditor dan satuan kerja. Pada instrumen wawancara, peneliti memeriksa dan menanyakan pandangan individu lain melalui instrumen diskusi grup dan dokumentasi. Perbedaan pernyataan informan akan didiskusikan melalui diskusi grup. Ada dua tolak ukur dalam penentuan keabsahan diskusi grup. Pertama, proses diskusi grup sesuai dengan prasyarat seperti homogenitas partisipan, spesifikasi topik (kualitas reviu laporan keuangan), kondusifnya lokasi, keberadaan pengamat sebagai pencatat perilaku nonverball, optimalnya jumlah partisipan, keakuratan seleksi partisipan, dan proses rangkaian diskusi grup, Kedua, tema diskusi grup sesuai untuk digali dengan metoda diskusi grup. Pembahasan kualitas reviu harus melalui diskusi dari pihak-pihak pelaksana reviu laporan keuangan.

\section{Hasil dan Pembahasan}

Bagian ini akan menguraikan ulasan tentang kualitas reviu Laporan Keuangan Kementerian Pariwisata dan kendala pelaksanaan reviu. 
Evaluasi Kualitas Reviu Laporan Keuangan Kementerian

\section{Kualitas Reviu}

Hasil kesesuaian pelaksanaan reviu atas Laporan Keuangan Kementerian Pariwisata didasarkan kesesuaian pelaksanaan dan kriteria dari sisi Inspektorat dan Satuan Kerja. Secara umum, persentase kesesuaian inspektorat sebesar $88,82 \%$ dari 12 kriteria, sedangkan satuan kerja mencapai $85 \%$ dari 10 kriteria. Nilai dari masing-masing kriteria pada reviu dari Inspektorat dapat dilihat pada Tabel 2 berikut.

Tabel 2

Hasil Evaluasi Pemenuhan Kriteria Reviu Inspektorat (Pihak Pereviu)

\begin{tabular}{ccc}
\hline Kriteria & Nilai Maksimal & Nilai \\
\hline 1 & 3 & 3 \\
2 & 6 & 5,5 \\
3 & 3 & 2,5 \\
4 & 2 & 2 \\
5 & 3 & 2,5 \\
6 & 3 & 3 \\
7 & 4 & 3,75 \\
8 & 2 & 2 \\
9 & 6 & 3,5 \\
10 & 2 & 2 \\
11 & 2 & 2 \\
12 & 2 & 2 \\
\hline Total & 38 & 33,75 \\
\hline Persentase Kualitas Reviu & 88,82 \\
\hline Selisih persentase untuk mencapai $100 \%$ & 11,18 \\
\hline
\end{tabular}

Sementara itu, ada perbedaan kriteria saat melaksanakan evaluasi satuan kerja. Dari total 12 kriteria, terdapat 2 kriteria, yakni sikap hatihati pereviu dan pelaksaan reviu sesuai dengan PKR (Program Kerja Reviu), adalah karakteristik dari inspektorat sebagai pereviu, bukan pihak yang direviu. Nilai dari masingmasing kriteria pada satuan kerja dapat dilihat pada Tabel 3.

Berikut adalah 12 kriteria dalam penilaian evaluasi reviu laporan keuangan kementerian.
Tabel 3

Hasil Evaluasi Pemenuhan Kriteria Reviu dari Satker (Pihak yang Direviu)

\begin{tabular}{ccc}
\hline Kriteria & Nilai Maksimal & Nilai \\
\hline 1 & 3 & 3 \\
2 & 6 & 4,5 \\
3 & 3 & 2,25 \\
4 & 2 & 1,5 \\
5 & 3 & 2,5 \\
6 & 3 & 2,75 \\
7 & 4 & 3,5 \\
8 & 2 & 1,5 \\
9 & 2 & 2 \\
10 & 2 & 2 \\
\hline Total & 30 & 25,5 \\
\hline Persentase Kualitas Reviu & 85 \\
\hline Selisih persentase untuk mencapai $100 \%$ & 15 \\
\hline
\end{tabular}

1. Evaluasi Pengalaman Tim Reviu atas Laporan Keuangan Kementerian

Pengalaman adalah atribut penting dalam pelaksanaan reviu karena banyaknya pengalaman akan menimalisir tingkat kesalahan. Pada kriteria ini, peneliti menekankan lama kerja atau pengalaman inspektorat. Penilaian dilakukan dari jenis pendidikan formal dan pengalaman kerja dalam reviu laporan keuangan kementerian. Skala penilaian didasarkan dari Peraturan Menteri Keuangan Nomor 41/PMK.09/2010 dan Pedoman Reviu Laporan Keuangan Inspektorat Jenderal Kementerian Kebudayaan dan Pariwisata Tahun 2010. Berdasarkan dua dokumen tersebut, peneliti memberikan skor maksimal 1 untuk pereviu dengan pengalaman 2 tahun, sedangkan pengalaman pereviu di bawah 2 tahun, peneliti menetapkan rumus skor dengan menghitung pembagian antara jumlah tahun pengalaman dibagi 2. Hasil penilaian peneliti menunjukkan bahwa pengendali teknis, ketua tim reviu, dan anggota dari masing-masing inspektorat dan satuan kerja memiliki nilai 1 . $\mathrm{Hal}$ ini menunjukkan bahwa Inspektorat 
Kementerian Pariwisata memiliki pengalaman yang mumpuni.

Sementara itu, dari aspek komposisi, tim reviu terdiri atas koordinator, pengendali teknis, ketua tim, dan anggota. Komposisi memiliki perbedaan pada dua perioda waktu tertentu, yakni antara 2012-2014 dan 2015. Pada tahun 2012 hingga 2014, Inspektur Jenderal adalah koordinator tim karena pada masa itu adalah unit kerja eselon 1. Namun, perubahan terjadi pada tahun 2015, yakni koordinator adalah inspektur karena unit kerja menjadi eselon 2 di bawah Sekretariat Kementerian Pariwisata. Komposisinya dapat dilihat pada Tabel 4 berikut.

Tabel 4 .

Komposisi Auditor Inspektorat per 1 Oktober 2016

\begin{tabular}{llll}
\hline No & Jenjang Jabatan & \multicolumn{1}{c}{ Peran } & Jumlah \\
\hline 1. Auditor Madya & Pengendali Teknis & 6 orang \\
2. Auditor Muda & Ketua Tim & 4 orang \\
3. Auditor Pertama & Anggota Tim & 8 orang \\
4. Auditor Penyelia & Anggota Tim & 1 orang \\
\hline Jumlah Pejabat Fungsional Auditor & 19 orang \\
\hline
\end{tabular}

Dari Tabel 4, dapat diketahui bahwa Auditor Madya berjumlah 6 orang, dengan 3 di antaranya berlatar belakang pendidikan akuntansi. Apabila ada penugasan reviu laporan keuangan, satu orang berperan sebagai pengendali teknis, sedangkan yang lain menjadi ketua dan anggota tim. Namun, apabila penugasan dilakukan pada tingkat satuan kerja atau UPT, para Auditor Madya berperan sebagai pengendali teknis pada masing-masing tim penugasan. Penjelasannya dapat terlihat pada kutipan wawancara berikut.

"Saya terkadang sebagai dalnis (pengendali teknis) ataupun sebagai ketua tim tergantung nanti apa substansinya. Sebelum mereviu di tingkat kementerian, auditor juga mereviu tingkat satuan kerja.
Kementerian kita memiliki lima satuan kerja yang punya kewajiban untuk menyusun laporan keuangan. Kita melakukan reviu satker sebagai dasar kita melakukan reviu laporan keuangan kementerian. Jadi kita dibagi menjadi lima tim, tim Satker 1 untuk laporan keuangan Satker 1, tim Satker 2 untuk laporan keuangan Satker 2, begitu seterusnya bingga Satker 5. UPT dan dekon/TP sekarang adanya di Satker 5 yaitu di tingkat eselon 1 saja. Saya termasuk tim yang memegang Satker 4, dalnis lain juga memegang masingmasing eselon 1. Tetapi untuk laporan keuangan tingkat kementerian kita timnya dirubab lagi jadi ada satu yang jadi dalnis, untuk ketua tim satu tetapi anggota tergantung penugasan dari pimpinan yaitu dari Pak Inspektur." (AM, Auditor Madya)

Kasus serupa terjadi saat Auditor Muda berperan sebagai anggota penugasan reviu laporan keuangan tingkat kementerian, tetapi menjadi ketua tim reviu tingkat satuan kerja atau UPT. Berikut penjelasan wawancaranya.

"Penugasan sifatnya ad boc karena timnya gabungan. Kondisi sekarang kita satu inspektur, kalau sebelumnya kita terbagi tiga inspektur. Kalau satu inspektur, inspektur memerintabkan satu dalnis atau beberapa dalnis sebagai koordinator. Ketua timnya juga dalnis karena kuota kebanyakan dalnis, para auditor muda ditugaskan sebagai anggota. Kecuali kalau ada turunan tugas lain yang terkait satker, di sini saya membidangi Satker 1. Satker 1 ini misalkan saya ditugaskan khusus oleh inspektur menjadi ketua tim. Tetapi kalau sifatnya gabungan atau tingkat kementerian, saya ikut komposisi tim yang ada. Karena komposisi dalnis sangat signifikan sebingga tidak mungkin semua auditor 
madya menjadi dalnis, jadi ada dalnis yang turun sebagai ketua tim, dan saya sebagai anggota."(AF, Auditor Muda)

\section{Evaluasi Pemahaman Entitas}

Pemahaman entitas mencakup gambaran atau informasi umum mengenai satuan kerja. Gambaran atau informasi umumnya adalah dasar hukum, keberlakuan peraturan perundang-undangan, tujuan organisasi, kegiatan operasional, metoda dan prosedur, keberlakuan kebijakan, permasalahan keuangan, dan informasi lapangan. Gambaran dan informasiinformasi itu akan membantu pereviu dalam menilai bidang yang memerlukan pertimbangan khusus, menilai kewajaran estimasi akan penilaian persediaan, menilai kondisi dan data akuntansi, dan mempertimbangkan kesesuaian penerapan prinsip akuntansi. Nilai pemahaman entitas dari inspektorat dan satuan kerja dapat dilihat.

Dari Tabel 5, dapat dinyatakan bawha sebagian besar anggota tim telah berpengalaman melakukan pemeriksaan reguler pada masing-masing satuan kerja, sehingga pemahaman entitas oleh pereviu sebagian besar sudah diperoleh pada saat melaksanakan audit reguler. Tanya jawab dengan pihak-pihak yang terlibat langsung dalam setiap proses transaksi maupun proses akuntansi untuk memperoleh pemahaman entitas yang direviu. Tanya jawab dilakukan jika pereviu membutuhkan klarifikasi atau permintaan keterangan mengenai penyampaian satuan kerja tentang transaksi atau akun dalam laporan keuangan. Hal ini didukung oleh pernyataan yang disampaikan oleh salah satu informan sebagai berikut.

"Dalam reviu laporan keuangan, kita klarifikasi misalkan ada terkait permasalaban dalam pencatatan, maka kita panggil pencatat barang milik negara. Kita panggil orang yang bertanggung jawab terhadap itu, dan kita klarifikasi. Sehingga secara otomatis muncul wawancara, tanya jawab." (AF, Auditor Muda)

Pernyataan informan di atas selaras dengan pernyataan informan berikut.

"Auditor datang untuk observasi dan mewawancarai saya. Kalau menanyakan tentang aset ke Sdr. NT sebagai operator SIMAK BMN.”(IF, operator SAI Satker 1)

Tabel 5

Hasil Evaluasi Pemahaman Entitas

\begin{tabular}{|c|c|c|c|}
\hline \multirow{2}{*}{ No } & \multirow{2}{*}{ Indikator Penilaian } & \multicolumn{2}{|c|}{ Nilai Evaluasi } \\
\hline & & Inspektorat & Satker \\
\hline 1. & $\begin{array}{l}\text { Pereviu mengumpulkan informasi/berita yang berkaitan dengan entitas } \\
\text { yang direviu. }\end{array}$ & 1 & 0,75 \\
\hline 2. & Pereviu membaca laporan hasil reviu entitas periode sebelumnya. & 1 & 0,75 \\
\hline 3. & $\begin{array}{l}\text { Pereviu membaca kebijakan pengelolaan keuangan dan/atau peraturan } \\
\text { menteri tentang sistem dan prosedur pengelolaan keuangan. }\end{array}$ & 0,75 & 0,75 \\
\hline 4. & Pereviu membaca kebijakan akuntansi. & 0,75 & 0,75 \\
\hline 5. & $\begin{array}{l}\text { Pereviu melakukan tanya jawab dengan pihak-pihak yang terlibat } \\
\text { langsung dalam setiap proses transaksi. }\end{array}$ & 1 & 0,75 \\
\hline 6. & $\begin{array}{l}\text { Pereviu melakukan tanya jawab dengan pihak-pihak yang terkait dalam } \\
\text { proses akuntansi. }\end{array}$ & 1 & 0,75 \\
\hline & Jumlah Nilai & 5,5 & 4,5 \\
\hline
\end{tabular}


Selain itu, ada pendapat lain dari suatu satuan kerja bahwa pereviu kurang memahami entitas yang direviu seperti tampak dalam kutipan wawancara berikut.

"Terkadang tim reviu kurang menguasai entitas yang direviu. Hal ini terjadi karena kemungkinan seringnya berganti anggota tim reviu untuk entitas satker." (SR, operator SAI Satker 2)

Alasannya, terkadang terdapat satu anggota tim berlatar belakang bukan akuntansi terlibat dalam penugasan reviu.

"Secara umum ada yang pabam tetapi ada juga beberapa anggota yang kurang pabam. Mungkin karena latar belakang keilmuan yang dimiliki. Karena kadang kita melibatkan orang yang latar belakangnya bukan keuangan atau akuntansi tiba-tiba dipaksa untuk reviu lk pasti prosesnya lebih sulit. Meskipun begitu yang memimpin pelaksanaan reviu adalab orang-orang yang berlatar belakang akuntansi. Kapabilitas atau kompetensinya itu belum memenubi standar, tetapi cuma sedikit.” (EB, Auditor Pertama)

\section{Evaluasi Sikap Responsif terhadap} Kebutuhan-kebutuhan Klien

Umumnya, klien akan mengalami masalah khusus, sehingga pereviu harus memiliki kemampuan analitikal dalam menanganinya. Klien memiliki dua karakteristik entitas, yakni entitas pelaporan dan entitas akuntansi. Saran dan rekomendasi pereviu tentang bebasnya penyajian laporan keuangan dari salah saji material dan memadainya penyusunan SPI harus mampu diberikan oleh pereviu. Tindakan persuasif dalam pelaksanaan saran dan rekomendasi adalah kewajiban pereviu agar klien mampu memperbaiki kesalahannya. Mekanisma ini berpotensi memakan waktu, sehingga baiknya pengelolaan waktu akan menjamin mutu dari reviu.

Penilaian sikap responsif memiliki 3 nilai indikator. Pertama, apabila tim reviu mampu menyelesaikan penugasan secara tepat waktu, maka skor mereka adalah 1. Apabila penyelesaian tidak tepat waktu, maka perhitungan akan disesuaikan dengan jawaban informan, dari sisi pereviu dan satuan kerja. Kedua, apabila tim reviu mampu memberikan saran dan rekomendasi, maka skor mereka adalah 1 . Namun, jika tidak ada saran dan rekomendasi, maka tidak ada nilai atau skor adalah 0. Ketiga, penilaian berkaitan dengan penyelesaian tindak lanjut hasil reviu dengan membandingkan jumlah rekomendasi tertindaklanjuti sebelum LHR terbit dan jumlah rekomendasi diberikan.

Pada indikator pertama, inspektorat dan satuan kerja secara bersamaan memiliki nilai 0,5. Kesamaan skor senada dengan indikator ketiga, yakni inspektorat dan satuan kerja dinilai mampu menindaklanjuti saran dan rekomendasi. Akan tetapi, perbedaan nilai terjadi pada indikator kedua, yakni Inspektorat memperoleh skor 1 , sedangkan satuan kerja mendapatkan skor 0,75 .

Dalam surat tugas reviu yang ditandatangani oleh Inspektur Kementerian Pariwisata disebutkan tanggal mulai dan berakhirnya reviu yang dilaksanakan. Dari hasil wawancara dengan para informan, ada yang mengatakan reviu selesai tepat waktu, tetapi ada pula yang mengatakan sebaliknya. Penyebabnya adalah pembagian tugas tim reviu di tingkat satuan kerja yang berbeda. Dampaknya, ada tim reviu yang dapat menyelesaikan secara tepat waktu dan ada yang melebihi batas waktu yang ditentukan karena memperoleh kendala. Hal tersebut sesuai dengan kutipan hasil wawancara yang diuraikan berikut. 
"Reviu memang harus selesai tepat waktu karena harus dateline dengan penyampaian laporan keuangan dari kementerian ke Kementerian Keuangan. Jadi kalau ini tidak tepat waktu berarti kan kita kena pinalti oleb Kementerian Keuangan, ini bisa dikategorikan sebagai salah satu indikasi ya dapatnya disclaimer itu karena mungkin ketepatan waktu itu mempengarubi jadi kita harus tepat waktu. Kalau misalkan akbir Februari itu misalkan tanggal 27 itu datelinenya sudab sampai di Kementerian Keuagan berarti paling akbir tanggal 27 itu sudah di laporan keuangan. Hasil reviu sudah ditandatangani oleb inspektur sedangkan laporan keuangannya ditandatangani oleh Pak Menteri itu akbir bulan Februari. Kalau ini tidak selesai, tidak dateline dengan waktunya, ini akan menjadikan catatan bagi Kementerian Keuangan mungkin jangkanya harus tepat waktu ya. Jadi selama ini kita tepat waktu Bu.”(AM, Auditor Madya)

Sedangkan auditor yang menjadi anggota tim reviu yang mengalami keterlambatan, tampak dari hasil wawancara berikut.

"Kalau per surat tugas ini kita hampir sepulub tabun lab melakukan tugas ini rata-rata diluar dari schedule. Misalkan tugasnya lima belas bari ternyata selesainya dua pulub hari. Banyak faktor kenapa bisa seperti itu Mbak. Pertama karena kesiapan dari pemeriksa, yang diperiksanya itu, terus waktu dari temanteman yang terlibat didalamnya, banyak faktor lah. Tetapi pada umumnya tidak tepat waktu."(AF, Auditor Muda)

Rekomendasi yang diberikan oleh tim reviu langsung ditindaklanjuti oleh satker. Rekomendasi tersebut dituangkan dalam Catatan Hasil Reviu (CHR). Apabila ada rekomendasi yang belum ditindaklanjuti, maka akan dimasukkan dalam LHR sebagai temuan. Hal tersebut sesuai dengan hasil wawancara berikut.

"Kita kan pararel ya di tingkat Eselon 1 atau di satker. Karena CHR kan intinya itu kita mereviu laporan keuangan tingkat satker atau tingkat Eselon 1 dulu. Nab di sana kan ada catatan-catatan, catatancatatan itu rekomendasinya bukan tingkat kementerian tetapi tingkat satker yang sudab dibagi-bagi per masing-masing unit. Misalnya saya megang Satker 4, nanti Partisipan 3 misalkan Satker 3, Partisipan 2 nanti kan Satker 2. Terus yang Satker 1 mungkin Pak AF cs nanti sama timnya, itu kita kan ada lima ya, yang Satker 5 ada Bu MR. Nab itu waktu pada saat proses CHR itu adanya di tingkat Eselon 1. Dan itu langsung ditindaklanjuti oleb tingkat Eselon 1 nya. Maka kalau misalkan tingkat kementerian itu sudab pararel setelah laporan keuangan jadi memang itu dari awal sudab didampingi. Sebingga itu pada dasarnya itu CHR yang sudah sampai tingkat kementerian itu yang sudab ditindaklanjuti." (AM, Auditor Madya)

\section{Evaluasi Kompetensi Teknis}

Kompetensi teknis adalah memadainya pengetahuan, keahlian, pengalaman, dan keterampilan tim pereviu. Berbagai macam pengetahuan seperti penguasaan SAP dan SAI, proses bisnis atau kegiatan pokok unit akuntansi, ilmu dasar audit, teknik komunikasi, dan analisis basis data, harus dikuasai oleh tim pereviu.

Pereviu yang bersertifikat auditor, baik Auditor Terampil maupun Auditor Ahli, bisa dikatakan telah memenuhi kompetensi karena telah lulus ujian Jabatan Fungsional Auditor (JFA) yang didalamnya terdapat materi Audit 
Intern, Komunikasi Audit Intern, serta Tata Kelola, Manajemen Risiko \& Pengendalian Intern. Selain itu, pemahaman mengenai halhal teknis tentang akuntansi khususnya reviu atas laporan keuangan kementerian dapat diperoleh dari bimbingan teknis maupun pendidikan dan pelatihan.

Indikator penilaian terhadap kompetensi teknis yang harus dimiliki oleh pereviu dilakukan dengan membandingkan jumlah anggota tim reviu yang berlatar belakang pendidikan akuntansi atau bersertifikat auditor dengan jumlah anggota tim reviu. Kemudian, membandingkan jumlah anggota tim reviu yang pernah mengikuti pelatihan reviu dibandingkan dengan jumlah anggota tim reviu. Hasil evaluasi menunjukkan bahwa masing-masing inspektorat dan satuan kerja memiliki sertifikasi auditor atau berlatar belakang pendidikan akuntansi, sehingga memiliki skor 1. Akan tetapi, ditemukan fakta bahwa belum setiap anggota tim reviu dan klien mengikuti pelatihan atau bimbingan teknis tentang reviu laporan keuangan kementerian, sehingga masing-masing inspektorat dan satuan kerja memperoleh skor 0,5.

Anggota tim reviu tidak semuanya berlatar belakang pendidikan akuntansi. Namun, anggota yang tidak berlatar belakang pendidikan akuntansi tersebut telah bersertifikat auditor sehingga bisa dikatakan telah memenuhi kompetensi. Pelaksanaan reviu juga melibatkan staf yang berlatar belakang pendidikan akuntansi dan telah lulus ujian sertifikasi JFA. Sehingga dari segi kompetensi teknis telah memenuhi syarat untuk bisa melakukan reviu atas laporan keuangan kementerian. Hal tersebut sesuai dengan hasil wawancara berikut.

"Calon auditor dilibatkan, karena apa meskipun dia misal belum memiliki kompetensi untuk sertifikasi reviu lk tetapi mereka yang calon auditor juga ada yang berbasis atau latar belakang akuntansi atau latar belakang sarjana ekonomi. Pada saat mereka pembekalan awal dia sebagai PNS mungkin dari segi pemahaman terkait laporan keuangan mereka sudab dapat ilmu dasarnya jadi kita hanya tinggal mengarabkan saja. Ketua tim mengarabkan dan mereviu hasil pekerjaan yang dilakukan oleb non auditor yang melakukan reviu. Dan nanti supervisi dari pengendali teknis terbadap etika pereviu dan kinerja auditor. Jadi ada dua yang disupervisi, pertama etikanya, kedua kinerjanya dalam mereviu laporan keuangan tingkat kementerian." (AM, Auditor Madya)

Hal tersebut juga dikemukakan oleh auditor yang pernah dilibatkan sejak masih menjabat sebagai staf, seperti tampak dalam kutipan wawancara berikut ini.

"Kalau saya ini karena masuk pertama kali sebagai PNS ini dari tabun 2006 itu sudah di inspektorat. Karena latar belakang saya ekonomi dan akuntansi, maka pada saat masuk saya langsung dilibatkan walaupun belum sebagai auditor. Saya baru diangkat sebagai auditor pada tabun 2010. Jadi saya diminta magang, istilab yang dipakai oleh para auditor madya. Saya magang empat tabun jadi secara langsung sudah hampir sepulub tabun ikut mereviu." (AF, Auditor Muda)

5. Evaluasi Komitmen yang Kuat terhadap Kualitas Reviu

Auditor dituntut untuk terus meningkatkan kompetensinya untuk dapat melaksanakan reviu yang berkualitas. Sebagai instansi APIP, Inspektorat wajib mendukung peningkatan kompetensi auditor dengan menyediakan prasarana dan sarana yang memadai. Salah satunya yaitu mendukung pelaksanaan 
kegiatan pelatihan atau bimbingan teknis yang dilakukan secara rutin, baik di internal organisasi maupun di luar instansi. Selain itu, penyediaan anggaran untuk membiayai kegiatan pendidikan dan pelatihan dalam rangka penjenjangan JFA Mandiri (pendidikan berkelanjutan). Intensitas pelatihan atau bimbingan teknis yang diikuti oleh auditor akan mempengaruhi peningkatan kompetensi yang dimilikinya.

Indikator pertama yang digunakan untuk mengukur komitmen terhadap kualitas reviu yaitu dengan melihat frekuensi pelaksanaan kegiatan PKS di Inspektorat Kementerian Pariwisata. Jika PKS dilaksanakan dua bulan sekali atau enam kali dalam setahun, maka akan diberikan skor 1, sedangkan untuk PKS yang dilaksanakan kurang dari enam kali maka diberikan skor sesuai jumlah PKS yang diselenggarakan dibagi empat. Indikator kedua yaitu ketersediaan anggaran dalam Dokumen Pelaksanaan Anggaran (DIPA) untuk membiayai kegiatan pendidikan dan pelatihan. Indikator ketiga yaitu dukungan Inspektur yang secara aktif mendorong staf mengikuti pelatihan atau bimbingan teknis dan ujian pada bidang akuntansi pemerintahan. Hasil investigasi peneliti menunjukkan bahwa masingmasing inspektorat dan satuan kerja memenuhi indikator pertama dan kedua dengan baik (skor 1). Sementara itu, ditemukan fakta bahwa satuan kerja kurang aktif mendorong stafnya untuk mengikuti pelatihan/bimbingan teknis. Skor satuan kerja pada indikator ketiga adalah 0,5 , sedangkan inspektorat turut berperan serta mengembangkan pemahaman stafnya pada akuntansi pemerintahan melalui pelatihan/ bimbingan teknis.

Hal tersebut dapat dilihat dari rutinnya pelaksanaan PKS dan dukungan terhadap auditor untuk melanjutkan pendidikan maupun pelatihan di bidang akuntansi pemerintahan seperti tampak dalam kutipan wawancara berikut.

"Ini pada dasarnya itu tim reviu ada yang sudah memahami dan ada yang belum. Maka dalam rangka reviu itu dilakukan PKS (Pelatiban di Kantor Sendiri). Fungsinya yaitu ketua tim dan dalnis mengarabkan auditor yang mungkin sudab pabam, tetapi kita lebih memperdalam lagi tentang Standar Akuntansi Pemerintah, Sistem Akuntansi Instansi, SAIBA, SIMAK BMN. Kalau tidak dibriefing lagi, mungkin mereka lupa. Jadi kita melakukan PKS (Pelatiban di Kantor Sendiri) sebelum pelaksanaan reviu."(AM, Auditor Madya)

6. Evaluasi Keterlibatan Pimpinan dalam Pelaksanaan Reviu

Pimpinan APIP merupakan sosok penting dalam pelaksanaan reviu atas laporan keuangan kementerian. Selain sebagai pihak yang menandatangani surat tugas, LHR, dan pernyataan telah direviu, juga melakukan koordinasi secara intensif dengan pihak terkait. Pihak tersebut antara lain yaitu penyusun laporan keuangan kementerian pada tingkat UAPA (Biro Perencanaan dan Keuangan Sekretariat Kementerian Pariwisata), dan penyusun laporan keuangan kementerian pada tingkat UAPPA-E1 (satker). Sehingga sangat penting untuk melakukan koordinasi secara intensif dengan pimpinan satker agar dapat mendukung para penyusun laporan keuangan kementerian yang ada dibawah kepemimpinannya.

Dari tahun 2012 hingga 2014, pendampingan dilakukan oleh Sekretaris Inspektorat Jenderal dan 3 Inspektur. Selama perioda tersebut, Inspektur Jenderal sebagai pihak yang menandatangani surat tugas, LHR, dan pernyataan telah direviu. Akan tetapi, untuk tahun 2015 hingga saat ini, hal tersebut 
dilakukan oleh seorang Inspektur. Selama kurun waktu tersebut dilakukan evaluasi keterlibatan pimpinan dalam pelaksanaan reviu atas laporan keuangan kementerian.

Pada aspek pendampingan pertemuan awal dan akhir, Inspektorat memperoleh skor 1, sedangkan satuan kerja memperoleh skor 0,75 . Sementara itu, baiknya pencapaian ditemukan pada dua aspek lainnya. Keterlibatan aktif pimpinan dari tahap perencanaan, proses, hingga penandatanganan hasil akhir, lalu adanya komunikasi antara pimpinan APIP dan pimpinan satuan kerja, telah terlaksana dengan baik pada inspektorat dan satuan kerja (masing-masing memperoleh skor 1). Berikut adalah hasil wawancara.

"Pak Inspektur mengarabkan, lalu beliau yang menjembatani kita dengan satker. Kalau masalab teknis pasti beliau tidak langsung terjun ke lapangan. Tetapi kalau misalkan menanyakan perkembangan, lalu ada masukan-masukan juga dari beliau. Kadang Pak Inspektur menanyakan permasalaban krusial dimana, kalau auditor menyampaikan babwa ada satker belum menyampaikan laporan keuangan, nanti beliau yang membantu menge-push. Beliau juga kadang-kadang bersedia mendatangi satkernya atau mengingatkan satkernya." (EB, Auditor Pertama)

7. Evaluasi Independensi dan Objektivitas
Setiap anggota tim reviu harus menjaga independensi dan obyektivitas dalam melaksanakan reviu agar lebih berkualitas. Sikap independensi tercermin dari tidak adanya kepentingan keuangan atau kepentingan lain yang dimiliki oleh tim reviu dan tidak mempunyai hubungan kerjasama dengan satker. Apabila terdapat gangguan independensi pada tim reviu, maka pereviu tersebut wajib menolak penugasan reviu. Selain itu, pereviu harus menjunjung tinggi independensi dalam mengumpulkan, mengevaluasi, dan memproses data atau informasi satker.

Hal tersebut tampak dalam kutipan wawancara berikut.

"Tidak ada gangguan independensi, untuk mengantisipasi kalau ada itu nanti dialibkan ke tim yang lain. Jadi misalkan kalau ada bubungan seperti suami istri atau saudara, kerabat, auditor tidak akan dimasukkan ke tim di tempat saudaranya di satker itu bekerja. Jadi nanti dialibkan ke tim yang lain. Jadi tidak ada." (EB, Auditor Pertama)

Hal sependapat dikemukakan oleh informan yang berasal dari satker sebagai berikut.

"Ada teman seangkatan yang menjadi auditor di inspektorat namun tidak pernab diaudit atau direviu mereka. Mungkin sengaja kan Mbak biar terpisah, dia selalu mengaudit atau mereviu ditempat lain." (IF, Operator SAI Satker 1).

Tabel 6.

Hasil Evaluasi Independensi dan Objektivitas

\begin{tabular}{llcc}
\hline \multirow{2}{*}{ No } & \multicolumn{2}{c}{ Indikator Penilaian } & \multicolumn{2}{c}{ Nilai Evaluasi } \\
\cline { 3 - 4 } & & Inspektorat & Satker \\
\hline 1. & Tidak adanya kepentingan keuangan secara langsung/tidak langsung & 1 & 1 \\
2. & Tidak adanya hubungan kerjasama & 1 & 0,75 \\
3. & Apabila ada indikasi pelanggaran, maka tim reviu menolak penugasan & 1 & 1
\end{tabular}




\begin{tabular}{lcc} 
4. Penilaian tidak memihak & 0,75 & 0,75 \\
\hline Jumlah Nilai & 3,75 & 3,5 \\
\hline
\end{tabular}

\section{Evaluasi Sikap Hati-hati Pereviu}

Dalam melaksanakan reviu atas laporan keuangan kementerian, pereviu harus bersikap hati-hati. Sikap hati-hati pereviu diwujudkan dengan melaksanakan reviu sesuai pedoman atau standar yang telah ditetapkan. Peraturan yang dijadikan pedoman yaitu PMK Nomor 41/PMK.09/2010 tentang Standar Reviu atas Laporan Keuangan Kementerian Negara/ Lembaga. Selain itu, sikap hati-hati pereviu juga dibuktikan dengan adanya dokumentasi yang lengkap mengenai prosedur reviu yang terangkum dalam KKR. KKR berisi catatancatatan dokumentasi tim reviu terkait pengumpulan bukti-bukti, penerapan teknik dan prosedur, dan penarikan kesimpulan penugasan reviu. Oleh karena itu, keberadaan KKR sangatlah penting. Tidak hanya sebagai acuan dalam membuat LHR, tetapi juga menjadi pedoman untuk pelaksanaan reviu di tahun berikutnya, serta menjadi bukti penting apabila pereviu diminta memberikan keterangan di pengadilan. Hasil penelusuran menunjukkan bahwa kesesuaian reviu dengan pedoman dan kelengkapan KKR masingmasing mencapai skor 1 . Hal tersebut tampak dalam kutipan wawancara berikut.

"Auditor wajib membuat kertas kerja reviu, setelab itu dibuat catatan basil reviu. Setelah catatan hasil reviu nanti dibuat laporan hasil reviu." (MH, Auditor Madya)

Hal sependapat dikemukakan oleh informan berikut ini.
"Masing-masing auditor membuat kertas kerja reviu. Karena kertas kerja reviu itu kewajiban dari para auditor sebagai bukti babwa kinerja dia itu disitu." (AF, Auditor Muda)

9. Evaluasi Pelaksanaan Reviu Sesuai dengan PKR

PKR berperan penting dalam pelaksanaan karena PKR merupakan prosedur dan teknik reviu yang disusun oleh ketua tim reviu secara sistematis yang harus diikuti dan dilaksanakan oleh tim reviu.

Indikator pertama untuk mengukur kesesuaian pelaksanaan reviu dengan PKR, yaitu ada tidaknya PKR. Jika tim reviu menyusun PKR, maka diberikan skor 1 . Namun, apabila tim reviu tidak membuat PKR, maka diberikan skor 0. Indikator kedua ialah kesesuaian PKR dengan pedoman PMK Nomor 41/PMK.09/2010 yaitu membuat langkah kerja reviu, teknik reviu, sumber data, pelaksana, dan waktu pelaksanaan. PKR yang lengkap diberi skor 1, sedangkan yang tidak lengkap dinilai sesuai dengan jumlah pemenuhan isi PKR dibagi 5. Adapun analisis terhadap penilaian SPI, dilakukan dengan melihat dokumen terkait penilaian SPI.

Dari Tabel 7 di bawah, dapat terlihat bahwa tim reviu Inspektorat Kementerian Pariwisata berpedoman pada PKR yang telah ditetapkan dan PKR yang disusun telah sesuai dengan pedoman PMK Nomor 41/PMK.09/ 2010 yang memuat langkah kerja reviu, teknik reviu, sumber data, pelaksana, dan waktu 
pelaksanaan. Hal tersebut sesuai dengan hasil wawancara berikut.

"Sebelum melakukan reviu pasti dibuat Program Kerja Reviu dulu ya karena disana kan ada pembagian tugas, ada batas-batas waktu yang harus dilakukan, ada kewajibankewajiban yang harus dilaksanakan ya.
Karena kalau tidak, biasanya tidak jelas ya untuk pembagian tugasnya. Tetapi dengan adanya Program Kerja Reviu itu mengatur siapa berbuat apa dan kapan pekerjaan itu barus selesai dilaksanakan." (AM, Auditor Madya)

Tabel 7

Hasil Evaluasi Pelaksanaan Reviu Sesuai dengan PKR

\begin{tabular}{|c|c|c|}
\hline No & Indikator Penilaian & Nilai Evaluasi \\
\hline & Terdapat PKR. & 1 \\
\hline 2. & $\begin{array}{l}\text { PKR memuat langkah kerja reviu, teknik reviu, sumber data, pelaksana, dan waktu } \\
\text { pelaksanaan. }\end{array}$ & 1 \\
\hline 3. & $\begin{array}{l}\text { Tim reviu melakukan penilaian terhadap sistem dan prosedur pengelolaan keuangan } \\
\text { negara. }\end{array}$ & 1 \\
\hline & $\begin{array}{l}\text { Tim reviu melakukan observasi dan/atau wawancara dengan pihak terkait di setiap } \\
\text { prosedur yang ada dan kemudian hasilnya didokumentasikan dalam tabel penilaian } \\
\text { SPI untuk setiap sub sistem yang telah dikembangkan. }\end{array}$ & 0,5 \\
\hline & $\begin{array}{l}\text { Tim reviu melakukan analisis atas risiko yang telah diidentifikasi pada sebuah } \\
\text { kesimpulan tentang kemungkinan terjadinya salah saji material dalam penyusunan } \\
\text { laporan keuangan yang hasilnya didokumentasikan dalam masing-masing tabel } \\
\text { penilaian SPI. }\end{array}$ & 0 \\
\hline & $\begin{array}{l}\text { Tim reviu melakukan analisis atas risiko yang telah diidentifikasi pada sebuah } \\
\text { kesimpulan tentang arah pelaksanaan reviu yang hasilnya didokumentasikan dalam } \\
\text { masing-masing tabel penilaian SPI. }\end{array}$ & 0 \\
\hline & Jumlah Nilai & 3,5 \\
\hline
\end{tabular}

10. Evaluasi Keterlibatan Tim Reviu Perioda Sebelumnya

Keterlibatan tim reviu periode sebelumnya diperlukan dalam mewujudkan pelaksanaan reviu yang berkualitas dan efektif. Dengan melibatkan pereviu sebelumnya, maka sebagian prosedur reviu bisa dilalui dengan lebih cepat karena telah memiliki informasi yang diperlukan. Tim reviu yang saat ini bertugas, hanya perlu melakukan penyesuaian apabila terjadi perubahan dalam entitas yang direviu. Selain itu dengan menggunakan KKR periode sebelumnya, maka akan membantu terwujudnya pelaksanaan reviu yang optimal dan tepat waktu. Hasil penelusuran menunjukkan bahwa
Inspektorat memperoleh skor 1 pada aspek keaktifan komunikasi dengan tim reviu sebelumnya dan penggunaan kertas kerja reviu sebelumnya. Sementara itu, satuan kerja memperoleh skor 0,75 .

Hal tersebut didukung dengan fakta bahwa beberapa anggota tim reviu di Inspektorat Kementerian Pariwisata dari tahun 2012 hingga 2015 masih terlibat dalam proses pelaksanaan reviu. Dampaknya, pengalaman tim reviu periode sebelumnya dapat digunakan untuk membantu mempermudah pelaksanaan reviu periode berikutnya. Hal ini sesuai dengan hasil wawancara yang diuraikan berikut. 
"Kalau di kementerian kita kan timnya hanya ini-ini saja. Jadi sudah pasti terlibat mereka". (MH, Auditor Madya)

Pernyataan informan mengenai penggunaan Kertas Kerja Reviu tahun lalu sebagai referensi dapat diketahui dari hasil wawancara berikut.

"Iya, untuk mengetahui kondisi entitas apakah ada perubahan atan tidak". (AF, Auditor Muda)

11. Evaluasi Ketaatan terhadap Kode Etik APIP

Kode etik APIP diatur dalam Permenpan No. PER/04/M.PAN/03/2008 tentang Kode Etik Aparat Pengawasan Intern Pemerintah. Melalu kode etik ini, diharapkan profesionalitas dan kualitas pengawasan auditor dapat terwujud. Dari hasil penelurusan, diperoleh skor 1 untuk masing-masing inspektorat dan satuan kerja dalam hal penerapan standar etika dan nihilnya pengaduan pelanggaran kode etik.

Dalam pelaksanaan reviu atas laporan keuangan kementerian oleh Inspektorat Kementerian Pariwisata, tidak ada indikasi pelanggaran kode etik yang dilakukan oleh tim reviu. Hal tersebut dibuktikan dengan tidak adanya pengaduan dari pihak luar terkait pelanggaran kode etik yang dilakukan ti reviu. Berdasarkan hal tersebut, dapat disimpulkan bahwa tim reviu Inspektorat Kementerian Pariwisata selalu menjunjung tinggi standar etika sebagai seorang APIP. Hal tersebut tercermin dalam kutipan wawancara berikut ini.

"Pelanggaran terhadap kode etik selama ini tidak ada. Pengaduan dari luar tidak ada juga, karena kita juga punya aplikasi WBS untuk mengapub pengaduan dari masyarakat atau pihak luar, ada juga kita mengapub pengaduan dari masyarakat. Sementara ini, sampai saat ini terbadap laporan keuangan dan tata cara mereviu belum ada masukan atau koreksi dari masyarakat jadi sementara masib lancar aman". (AM, Auditor Madya)

\section{Evaluasi Sikap Skeptis}

Dengan adanya sifat skeptis, maka akan membuat seorang pereviu melaksanakan tugas dengan cermat dan tepat di setiap prosedur. Perwujudan sikap skeptis dalam melaksanakan reviu melalui sikap selalu mempertanyakan dan melakukan evaluasi secara kritis terhadap penyajian laporan keuangan kementerian. Selain itu, tim reviu juga tidak menganggap bahwa penanggung jawab laporan keuangan satker yang direviu tidak jujur, tetapi juga tidak menganggap bahwa kejujuran penanggung jawab tersebut tidak diragukan lagi. Dari hasil penelusuran, peneliti menemukan bahwa masing-masing inspektorat dan satuan kerja layak diberikan skor 1.

Tim reviu Inspektorat Kementerian Pariwisata selalu menerapkan prosedur reviu dengan sebaik-baiknya. Penerapan tersebut meliputi upaya penelusuran angka, permintaan keterangan, dan prosedur analitis untuk memperoleh keyakinan yang memadai bahwa angka-angka yang disajikan dalam laporan keuangan tersebut bebas dari salah saji material. Dengan demikian, menunjukkan bahwa tim reviu tidak langsung mempercayai kebenaran penyajian laporan keuangan yang disusun oleh entitas pelaporan. Hal ini tercermin dalam kutipan wawancara dengan informan sebagai berikut.

"Pencairannya susab segala macem. Tetapi kayaknya alasan saja itu. Makanya nanti pas saat reviu di berikutnya, nanti kita libat lagi. Harusnya sib sudah, harusnya sib dipaksa kan kita sudab mengirim surat juga lewat sesmen suratnya. Masak mereka tidak menindaklanjuti." (EB, Auditor Pertama) 


\section{Kendala Reviu}

Belum optimalnya pelaksanaan reviu Laporan Keuangan Kementerian Pariwisata disebabkan oleh sejumlah persoalan. Peneliti menemukan bahwa 5 kendala menjadi penghambat belum maksimalnya implementasi mutu dan kualitas reviu. Berikut adalah 5 kendala yang dihadapi.

1. Keterlambatan Satker dalam Menyampaikan Laporan Keuangan

Keterlambatan satker dalam menyusun laporan keuangan merupakan salah satu kendala dalam pelaksanaan reviu atas laporan keuangan kementerian yang dilaksanakan oleh Inspektorat Kementerian Pariwisata. Keterlambatan tersebut antara lain dikarenakan terlambat menyampaikan dokumen sumber. Banyaknya satker dekon/TP menjadi salah satu pemicu keterlambatan satker dalam menyusun laporan keuangan karena periode 2012-2014 belum ada e-rekon sehingga operator SAI satker pusat mengalami kesulitan dalam melakukan konsolidasi laporan keuangan. Dengan adanya updating aplikasi yang dikeluarkan oleh Kementerian Keuangan menyebabkan versi terbaru tidak sinkron antara aplikasi satker dengan aplikasi $\mathrm{K} / \mathrm{L}$. hal tersebut mengakibatkan data antara satker dan kementerian berbeda. Sinkronisasi antara SAI dengan SIMAK BMN dan perbedaan akun juga menjadi kendala penyusunan laporan keuangan. Penjenjangan menjadi kendala bagi penyusun laporan keuangan kementerian untuk menyampaikan data laporan keuangan kementerian secara keseluruhan.

\section{Perubahan Nomenklatur}

Perubahan nomenklatur yang dialami oleh Kementerian Pariwisata menjadi salah satu kendala dalam pelaksanaan reviu laporan keuangan kementerian. Mulai dari perubahan struktur organisasi yang membutuhkan banyak penyesuaian, termasuk bergantinya penang- gung jawab dan penyusun laporan laporan keuangan. Perubahan nomenklatur dari Kementerian Kebudayaan dan Pariwisata menjadi Kementerian Pariwisata, menjadi kendala yang sangat berarti karena adanya aset yang belum diserahterimakan. Hal tersebut mengakibatkan pencatatan aset yang ada di Kementerian Pariwisata tidak sesuai.

3. Keterbatasan Jumlah dan Kompetensi Auditor

Faktor Sumber Daya Manusia (SDM) yang menjadi kendala pelaksanaan reviu antara lain terbatasnya jumlah auditor, auditor yang mempunyai latar belakang pendidikan akuntansi masih terbatas, kompetensi teknis auditor dalam hal ini tentang pemahaman aplikasi SAI, serta kurangnya pemahaman entitas yang dimiliki oleh auditor. Kurangnya koordinasi tim reviu dan koordinasi antara pereviu dengan satker juga menjadi kendala dalam pelaksanaan reviu atas laporan keuangan kementerian.

\section{Keterbatasan Waktu}

Tuntutan reviu yang berkualitas dengan waktu yang terbatas merupakan tekanan tersendiri bagi Inspektorat Kementerian Pariwisata. Hal ini karena dalam kompleksitas tugas yang tinggi dan waktu yang terbatas. Dengan adanya beban tugas lain yang diberikan selama pelaksanaan reviu menjadi berkurangnya alokasi waktu yang digunakan untuk melaksanakan reviu secara optimal.

\section{Kurangnya Dukungan Anggaran}

Kebijakan pimpinan dalam mengalokasikan anggaran akan turut mempengaruhi kualitas reviu yang dilakukan oleh Inspektorat Kementerian Pariwisata. Kurangnya dukungan prasarana dan sarana mengakibatkan pereviu tidak dapat melaksanakan tugasnya dengan optimal.

\section{Kesimpulan}


Riset ini bertujuan untuk mengevaluasi kualitas reviu atas laporan keuangan Kementerian Pariwisata dan menganalisis faktor yang menjadi kendala yang dihadapi oleh Inspektorat Kementerian Pariwisata dalam pelaksanaan reviu atas laporan keuangan yang dilakukan oleh Inspektorat Kementerian Pariwisata dari tahun 2012 hingga 2014. Berdasarkan hasil analisis data dengan menggunakan wawancara, FGD, dan telaah dokumen, diperoleh simpulan bahwa kualitas reviu laporan keuangan yang dilakukan oleh Inspektorat Kementerian Pariwisata mencapai kualitas yang baik dengan kriteria reviu yang berkualitas. Adapun tingkat kesesuaian yang menunjukkan kualitas reviu yaitu memperoleh $88,82 \%$. Berdasarkan hasil tersebut dapat diartikan bahwa reviu yang dilakukan oleh Inspektorat Kementerian Pariwisata termasuk dalam kategori reviu yang berkualitas baik. Meskipun memiliki kualitas yang bagus, pada tahun 2012 reviu Kementerian Pariwisata masih mendapat opini WDP dan disclaimer di tahun 2013-2014. Hal tersebut karena reviu dan audit memiliki tujuan dan prosedur yang berbeda. Inspektorat Kementerian Pariwisata tidak mereviu SPI sehingga tidak terdapat nilai reviu untuk SPI. Sedangkan BPK mempertimbangkan SPI Kementerian Pariwisata untuk menentukan prosedur pemeriksaan dengan tujuan untuk menyatakan pendapat atas laporan keuangan.

Kendala Pelaksanaan Reviu atas Laporan Keuangan Kementerian Periode 2012-2014 antara lain (1) keterlambatan satker dalam menyampaikan laporan keuangan, (2) perubahan nomenklatur, (3) keterbatasan jumlah dan kompetensi auditor, (4) keterbatasan waktu, dan (5) kurangnya dukungan anggaran.

\section{Daftar Pustaka}

Arens, A.A., Elder, R.J. \& Beasley, M.S., 2012, Auditing: Assurance services an integrated approach, Prentice Hall Business Publishing, New Jersey.

Badan Pemeriksa Keuangan Republik Indonesia, 2013, Laporan Hasil Pemeriksaan BPK RI Tabun 2013, Jakarta.

Badan Pemeriksa Keuangan Republik Indonesia, 2014, Laporan Hasil Pemeriksaan BPK RI Tabun 2014, Jakarta.

Badan Pemeriksa Keuangan Republik Indonesia, 2015, Laporan Hasil Pemeriksaan BPK RI Tabun 2015, Jakarta.

Badan Pemeriksa Keuangan Republik Indonesia, 2015, Laporan Hasil Pemeriksaan BPK RI Atas Laporan Keuangan Kementerian Pariwisata Tabun 2014 Nomor 133A/HP/XVI/05/2015, Jakarta

Behn, B. K., Carcello, J. V., Hermanson, D. R. \& Hermanson, R. H., 1997, 'The determinants of audit client satisfaction among clients of Big 6 firms', Accounting Horizons 11 (1), 7-24.

Creswell, J.W., 2014, Research Design (Qualitative, Quantitative and Mix Methods Approaches), Sage Publications, London.

Dona, S., 2013, 'Evaluasi Pelaksanaan Reviu atas Laporan Keuangan Pemerintah Daerah (Studi pada Inspektorat Kota Payakumbuh)', Tesis tidak diterbitkan, Universitas Gadjah Mada, Yogyakarta.

Gau, A.I., 2016, Analisis Kualitas Reviu atas Laporan Keuangan Satuan Kerja Perangkat Daerah (Studi pada Inspektorat Kabupaten Klaten), Tesis tidak diterbitkan, Universitas Gadjah Mada, Yogyakarta

Hartono, J., 2010, Metodologi Penelitian Bisnis, BPFE, Yogyakarta.

Hennink, M., Hutter, I. \& Bailey, A., 2011, Qualitative research method, SAGE Publications, London. 
Herdiansyah, H., 2015, Wawancara, Observasi, dan Focus Groups: sebagai Instrumen Penggalian Data Kualitatif, PT Rajagrafindo Persada, Depok.

Kuntadi, C., 2009, 'Peningkatan Kapabilitas Auditor Internal dalam Pelaksanaan Reviu atas Laporan Keuangan', Majalah Dwiwulanan BPK RI, Nomor118/Edisi Agustus-September 2009/Tahun XXVII, ISSN 0216-8154

Miles, M.B. dan Huberman, A.M., 1984, Qualitative Data Analysis, Sage Publications, Beverly Hills.

Moleong, L.J., 2016, Metodologi Penelitian Kualitatif, PT Remaja Rosdakarya, Bandung.

Mulyadi, 2002, Auditing, Salemba Empat, Jakarta.

Republik Indonesia, 2006, Peraturan Direktur Jenderal Perbendaharaan Nomor PER44/PB/2006 tentang Pedoman Pelaksanaan Reviu Laporan Keuangan Kementerian Negara/Lembaga, Jakarta.

Republik Indonesia, 2008, Peraturan Pemerintah Nomor 60 Tabun 2008 tentang Sistem Pengendalian Intern Pemerintah, Jakarta.

Republik Indonesia, 2008, Peraturan Menteri Pendayagunaan Aparatur Negara Nomor PER/05/M.PAN/03/2008 tentang Standar Audit APIP, Jakarta.

Republik Indonesia, 2010, Peraturan Pemerintah Nomor 71/2010 tentang Standar Akuntansi Pemerintah, Jakarta.
Republik Indonesia, 2010, Peraturan Menteri Keuangan Nomor 41/PMK.09/2010 tentang Standar Reviu atas Laporan Keuangan Kementerian Negara/Lembaga, Jakarta.

Republik Indonesia, 2012, Peraturan Menteri PAN E RB Nomor 28 Tabun 2012 tentang Pedoman Telaah Sejawat, Jakarta.

Republik Indonesia, 2015, Peraturan Menteri Pariwisata Nomor 6 Tabun 2015 tentang Organisasi dan Tata Kerja Kementerian Pariwisata, Jakarta.

Republik Indonesia, 2016, Peraturan Menteri Pariwisata Nomor 6 Tabun 2016 tentang Penyelenggaraan Sistem Pengendalian Intern Pemerintah di Lingkungan Kementerian Pariwisata, Jakarta.

Rai, I.G.A., 2008, Audit kinerja pada sektor publik: Konsep, praktik, dan studi kasus, Salemba Empat, Jakarta.

Miles, M. B. \& Huberman, A. M., 1984, Qualitative data analysis, SAGE Publications, Beverly Hills.

Ritonga, I. T., 2010, Reviu laporan keuangan pemerintah daerah, Yogyakarta, Lembaga Kajian Manajemen Pemerintah Daerah.

Tjiptono, F., 2007, Strategi pemasaran, Yogyakarta, Andi Offset.

Windarsih, D., 2015, 'Hubungan kualitas reviu laporan keuangan dengan temuan pemeriksaan BPK pada Pemerintah Kabupaten/ Kota se-DIY', Tesis tidak diterbitkan, Universitas Gadjah Mada, Yogyakarta. 